\title{
The regulation of gluconeogenesis by diet and insulin in rainbow trout (Salmo gairdneri)
}

\author{
By C. B. COWEY, D. KNOX, M. J. WALTON AND J. W. ADRON \\ Institute of Marine Biochemistry, St Fittick's Road, Aberdeen AB1 3RA
}

(Received 4 January 1977 - Accepted 6 April 1977)

1. The effects of diet composition and insulin treatment on blood glucose level, blood amino acid concentrations, the activities of two hepatic gluconeogenic enzymes (fructose diphosphatase, EC 3.1.3.11; phosphoenolpyruvate carboxykinase, $E C 4.1 .1 .32$ ) and of two hepatic glycolytic enzymes (hexokinase, EC 2.7.1.1; pyruvate kinase, EC 2.7.1.40) were examined in rainbow trout (Salmo gairdneri).

2. Blood glucose levels were much higher in trout given a high-carbohydrate (HC) diet than in those given a high-protein (HP) diet. Insulin reduced blood glucose concentration in the HC-fed fish but had no effect in HP-fed fish.

3. Plasma amino acid concentrations were higher in HP-fed trout than in HC-fed trout. Insulin reduced plasma amino acid levels in both groups.

4. Gluconeogenic enzyme activities were higher in HP-fed trout than in HC-fed trout. Insulin reduced phosphoenolpyruvate carboxykinase activity in HP-fed trout but had no effect on either enzyme activity in the HC-fed trout.

5. Pyruvate kinase activity was greater in HC-fed trout than in HP-fed trout. Insulin did not affect pyruvate kinase activity in the HC-fed trout but reduced it in HP-fed trout.

6. Hexokinase activity was not affected by the diet treatments used, but was enhanced in the trout treated with insulin. Glucokinase ( $E C$ 2.7.1.2) was not detected in any of the trout livers.

7. The results suggest that the inability of trout to control blood glucose concentration is partly due to a lack of glucose-phosphorylating capacity. Gluconeogenesis is controlled in response to diet and insulin by changes in enzyme level and by variation in concentration of gluconeogenic substrates.

We have shown that dietary and hormonal factors have effects on the rate of gluconeogenesis in carnivorous fish similar to those occurring in omnivorous mammals (Cowey, Higuera \& Adron, 1977). Thus the rate of gluconeogenesis from alanine was markedly reduced in trout (Salmo gairdneri) given a diet containing large amounts of carbohydrate compared with starved trout or those given a high-protein diet. Similarly, administration of insulin reduced the rate of gluconeogenesis in both starved trout and those given diets of high-protein content.

In omnivorous mammals fuel homoeostasis is controlled or largely influenced by insulin, but fish have been considered deficient in an endocrine mechanism which could regulate carbohydrate metabolism (Palmer \& Ryman, 1972). Thus it is of interest to examine, in more detail, both the manner in which diet composition regulates gluconeogenesis in fish and the effect of insulin on this dietary control.

Therefore the activities of two gluconeogenic enzymes, phosphoenolpyruvate carboxykinase (EC 4.1.1.32; PEPCK) and fructose diphosphatase (EC 3.1.3.11; FDP) and of two enzymes involved in glucose utilization, hexokinase $(E C 2.7 .1 .1 ; \mathrm{HK})$ and pyruvate kinase $(E C 2.7 .1 .40 ; \mathrm{PK})$ were measured in the livers of trout given diets containing high levels of either carbohydrate $(550 \mathrm{~g} / \mathrm{kg} ; \mathrm{HC})$ or protein $(600 \mathrm{~g} / \mathrm{kg}$; HP). Also concentrations of amino acids, which are quantitatively the most important gluconeogenic substrates available to the fish were measured in the plasma of fish given these diets; finally the effects of insulin (treatment superimposed) on liver enzyme activities and plasma amino acid levels of fish given these diets were examined.

The activities of both gluconeogenic enzymes were reduced in trout given a $\mathrm{HC}$ diet. HK activity was unaffected by diet composition and glucokinase (EC 2.7.1.2; GK) 


\section{C. B. Cowey, D. Knox, M. J. Walton And J. W. Adron}

activity was not induced. These findings go some way to explaining why gluconeogenesis is affected by diet composition while blood glucose level is not closely controlled. In trout given a HP diet insulin reduced PEPCK activity, and in those fish given a $\mathrm{HC}$ diet this hormone increased $\mathrm{HK}$ activity but did not induce $\mathrm{GK}$ activity. These results partly explain the effect of insulin in suppressing gluconeogenesis and in lowering blood glucose level.

\section{EXPERIMENTAL}

\section{Animals, diets and experimental treatments}

Rainbow trout of mean weight $67.5 \mathrm{~g}$ were obtained from D. M. Brien, Almondbank, Perth, and randomly distributed between six tanks at the rate of fifteen fish/tank. Tank dimensions, aquarium conditions and feeding methods were as described previously (Cowey et al. 1977). The compositions of the HC and HP diets were also described previously (Cowey et al. 1977). All fish were given the HP diet for 6 weeks, when their mean ( \pm SE) weight was $122 \cdot 2 \pm 10.8 \mathrm{~g}$. Fish in three of the tanks were then either analysed directly or subjected to insulin or streptozotocin treatment before analysis. Trout in the remaining tanks were given the $\mathrm{HC}$ diet for 6 weeks, by when their mean weight was $145.5 \pm 16.0 \mathrm{~g}$ they were then analysed either directly or after insulin or streptozotocin treatment.

Beef insulin (Sigma (London) Chemical Co. Ltd, Norbiton, Surrey) was injected intraperitoneally at the rate of $4 \mathrm{U} / \mathrm{kg}$ fish. Trout were given injections on successive days and analysed on the third day $72 \mathrm{~h}$ after the first injection. Streptozotocin (The Upjohn Co., Kalamazoo, Michigan, USA) was administered intravenously as described by Bloxam (1972) and the trout analysed $8 \mathrm{~d}$ later. All analyses were performed on six fish/treatment.

\section{Plasma amino acids, glucose and liver glycogen}

Trout were killed by a sharp blow on the head and blood taken from the caudal vein using EDTA as the anticoagulant. After removing erythrocytes by centrifugation a portion of the plasma was deproteinized by adding 3 vol. sulphosalicylic acid $(30 \mathrm{~g} / 1)$. After adjustment of the $\mathrm{pH}$ of the supernatant fraction and dilution when appropriate, amino acids were resolved and estimated using an amino acid analyser (model JLC-6AH, Jeol (UK) Ltd, Grove Park, London).

A further portion of the plasma was deproteinized with $3 \mathrm{~m}$-perchloric acid and glucose measured in the supernatant fraction by a glucose oxidase method (Krebs, Dierks \& Gascoyne, 1964). Liver glycogen was also measured by the glucose oxidase method after isolation and hydrolysis of the glycogen (Johnson \& Fusaro, 1966).

\section{Enzyme assays}

PEPCK was assayed in the 'forward' direction (oxaloacetate $\rightarrow$ phosphoenolpyruvate) by the method of Seubert \& Huth (1965) and in the 'back' direction by the method of Ballard \& Hanson (1967). Tissue extraction and assay conditions were as described by Pogson \& Smith (1975) except that extracts were sonicated five times for periods of $20 \mathrm{~s}$ in a sonicator (Measuring and Scientific Equipment Ltd, Buckingham Gate, London) at maximum power before centrifugation.

Total PK activity was extracted and assayed as described by Pogson (1968). The extraction buffer was $20 \mathrm{~mm}$-imidazole, $5 \mathrm{~mm}$-EDTA, $10 \mathrm{~mm}$-2-mercaptoethanol, $\mathrm{pH} \mathrm{6.8.} \mathrm{The}$ assay medium contained $125 \mathrm{mM}$-Tris-chloride, $12.5 \mathrm{mM}-\mathrm{MgCl}_{2}, 150 \mathrm{mM}-\mathrm{KCl}, 2 \mathrm{mM}-$ ADP, $1.5 \mathrm{~mm}$ phosphoenolpyruvate, $0.125 \mathrm{~mm}-\mathrm{NADH} \mathrm{pH} 7.4$ at $15^{\circ} ; 5$ units (1 unit catalyses the disappearance of $1 \mu$ mole pyruvate/min) lactate dehydrogenase $(E C 1.1 .1 .27)$ were used in a final volume of $3.0 \mathrm{ml}$ for the assay.

FDP was extracted and assayed as described by Opie \& Newsholme (1967). An ATP- 
Table 1. The effect of treatment with insulin on blood glucose (mmol/l) and liver glycogen ( $\mathrm{g} / \mathrm{kg}$ wet weight) in rainbow trout (Salmo gairdneri) given diets of different composition*

(Mean values with their standard errors for six fish/group)

\begin{tabular}{|c|c|c|c|c|c|c|c|c|c|}
\hline \multirow{3}{*}{ Diet . } & \multirow{2}{*}{\multicolumn{4}{|c|}{ High protein (HP) }} & \multirow{2}{*}{\multicolumn{2}{|c|}{ High carbohydrate $(\mathrm{HC})$}} & \multicolumn{3}{|c|}{$\begin{array}{l}\text { Statistical significance of } \\
\text { treatment: } p\end{array}$} \\
\hline & & & & & & & \multirow{3}{*}{$\begin{array}{c}\text { HP } \\
v . \\
\text { HP } \\
\text { insulin- } \\
\text { treated }\end{array}$} & \multirow{3}{*}{$\begin{array}{l}\mathrm{HP} \\
v . \\
\mathrm{HC}\end{array}$} & \multirow{3}{*}{$\begin{array}{c}\mathrm{HC} \\
\boldsymbol{v} \\
\mathrm{HC} \\
\text { insulin } \\
\text { treated }\end{array}$} \\
\hline & \multicolumn{2}{|c|}{ None } & \multicolumn{2}{|c|}{ Insulin } & None & Insulin & & & \\
\hline reatment & Mean & SE & Mean & SE & Mean SE & Mean SE & & & \\
\hline $\begin{array}{l}\text { llood glucose } \\
\text { iver glycogen }\end{array}$ & $\begin{array}{l}1.56 \\
15.0\end{array}$ & $\begin{array}{l}0.33 \\
2.0\end{array}$ & $\begin{array}{l}1.56 \\
12.0\end{array}$ & $\begin{array}{l}0 \cdot 17 \\
2 \cdot 0\end{array}$ & $\begin{array}{cc}6.11 & 1.22 \\
73.0 & 12.0\end{array}$ & $\begin{array}{cc}1.89 & 0.39 \\
52.0 & 22.0\end{array}$ & $\begin{array}{l}\text { NS } \\
\text { NS }\end{array}$ & $\begin{array}{r}<0.01 \\
0.02<\end{array}$ & $\begin{array}{c}<0.01 \\
5 \text { NS }\end{array}$ \\
\hline
\end{tabular}

NS, not significant $(P>0.05)$.

* For details, see p. 464.

generating system was included in the assay system (Newsholme \& Crabtree, 1970) to prevent possible AMP inhibition of FDP.

HK and GK were extracted and assayed by the method of Burleigh \& Schimke (1968) except that 6-phosphogluconate dehydrogenase $(E C 1.1 .1 .49)$ was added to the spectrophotometer cuvette; the change in extinction at $340 \mathrm{~nm}$ was thereby doubled and measurement of HK activity facilitated. For HK determinations glucose was present at a final concentration of $1 \mathrm{mM}$, for GK determination the glucose concentration was $40 \mathrm{~mm}$.

All spectrophotometric assays were performed at $15^{\circ}$ using a Unicam 1700 spectrophotometer (Pye Unicam Ltd, York Street, Cambridge).

\section{Chemicals}

Tris, imidazole, 2-mercaptoethanol, dithiothreitol were from Sigma (London) Chemical Co. Analytical enzymes, co-enzymes and substrates were obtained from Boehringer Corporation (UK) Ltd, Lewes, Sussex. $\mathrm{NaH}^{14} \mathrm{CO}_{3}$ was purchased from the Radiochemical Centre, Amersham, Bucks. Other chemicals were of the purest grade available from BDH Chemicals Ltd, Poole, Dorset.

\section{RESULTS \\ Blood glucose}

Values for hepatosomatic index (liver weight $\times 100 \div$ body-weight) in trout given the HC and HP diets were (mean $\pm \mathrm{SE}$ ) $1.68 \pm 0.13$ and $1.37 \pm 0.09$ respectively. These values were not significantly different $(0.1>P>0.05)$, therefore measurements on enzymes and glycogen in liver were expressed on a per $g$ wet liver basis.

Blood glucose and liver glycogen levels in trout subjected to the different experimental treatments are shown in Table 1. Comparison of the values obtained confirmed that trout have a poor homoeostatic mechanism to control blood glucose concentration. Thus blood glucose levels were 3-4-fold higher in trout given the $\mathrm{HC}$ diet than in those given the HP diet. Insulin treatment had no effect on blood glucose or liver glycogen levels in the trout given the HP diet, but significantly decreased blood glucose concentration in trout given the high carbohydrate diet.

\section{Liver enzymes}

The activities of the various enzymes studied are shown in Table 2. PK activity in the liver of trout given a $\mathrm{HC}$ diet was significantly greater than in trout given a HP diet. This is in line with expectation in that a similar adaptive change has been demonstrated in rats in 
Table 2. The effect of treatment with insulin on activities ( $\mu$ mol substrate converted/g wet tissue per h) of pyruvate kinase (EC 2.7.1.40) phosphoenolpyruvate carboxykinase (EC 4.1.1.32) hexokinase (EC 2.7.1.1) and fructose diphosphatase (EC 3.1.3.11) in the livers of rainbow trout (Salmo gairdneri) given diets of different composition*

(Mean values with their standard errors for six fish/group)

\begin{tabular}{|c|c|c|c|c|c|c|c|c|c|c|c|}
\hline \multirow{4}{*}{$\begin{array}{l}\text { Diet ... } \\
\text { Treatment }\end{array}$} & & & & & \multirow{2}{*}{\multicolumn{4}{|c|}{$\begin{array}{l}\text { High carbohydrate } \\
\text { (HC) }\end{array}$}} & \multicolumn{3}{|c|}{$\begin{array}{c}\text { Statistical significance of } \\
\text { treatment: } p\end{array}$} \\
\hline & \multicolumn{4}{|c|}{ High protein (HP) } & & & & & \multirow{3}{*}{$\begin{array}{c}\text { HP } \\
v . \\
\text { HP } \\
\text { insulin- } \\
\text { treated }\end{array}$} & \multirow{3}{*}{$\begin{array}{c}\mathrm{HP} \\
v, \\
\mathrm{HC}\end{array}$} & \multirow{3}{*}{$\begin{array}{c}\mathrm{HC} \\
\boldsymbol{v} . \\
\mathrm{HC} \\
\text { insulin- } \\
\text { treated }\end{array}$} \\
\hline & \multicolumn{2}{|c|}{ None } & \multicolumn{2}{|c|}{ Insulin } & \multicolumn{2}{|c|}{ None } & \multicolumn{2}{|c|}{ Insulin } & & & \\
\hline & Mean & SE 1 & Mean & SE & Mean & SE & Mean & SE & & & \\
\hline Pyruvate kinase & 259 & 20 & 148 & 6 & 426 & 38 & 486 & 56 & $<0.01$ & $\begin{array}{l}>0.01 \\
<0.02\end{array}$ & NS \\
\hline $\begin{array}{l}\text { Phosphoenol } \\
\text { pyruvate } \dagger \\
\text { carboxykinase }\end{array}$ & $102 \cdot 6$ & $22 \cdot 2$ & $54 \cdot 0$ & $10 \cdot 2$ & $40 \cdot 8$ & $12 \cdot 0$ & $54 \cdot 0$ & $17 \cdot 4$ & $\begin{array}{l}>0.01 \\
<0.02\end{array}$ & $<0.01$ & NS \\
\hline $\begin{array}{l}\text { Phosphoenol } \\
\text { pyruvate } \\
\text { carboxykinase }\end{array}$ & $90 \cdot 0$ & $17 \cdot 4$ & $37 \cdot 1$ & $8 \cdot 0$ & 27.0 & $10 \cdot 2$ & $38 \cdot 4$ & $15 \cdot 6$ & $<0.01$ & $<0.01$ & NS \\
\hline Hexokinase & $8 \cdot 70$ & 0.45 & $7 \cdot 94$ & 1.59 & 8.47 & 1.03 & $22 \cdot 0$ & $4 \cdot 38$ & NS & NS & $\begin{array}{l}>0.02 \\
<0.05\end{array}$ \\
\hline $\begin{array}{l}\text { Fructose } \\
\text { diphosphatase }\end{array}$ & $90 \cdot 3$ & $\begin{array}{l}6.2 \\
* \mathrm{~F} \\
+\mathrm{O} \\
\pm \mathrm{P} \\
\mathrm{NS}\end{array}$ & $\begin{array}{l}82.6 \\
\text { Oor deta } \\
\text { haloace } \\
\text { hospho } \\
\text { not sig }\end{array}$ & $\begin{array}{l}3 \cdot 13 \\
\text { ails, se } \\
\text { etate } \\
\text { oenolp } \\
\text { gnifica }\end{array}$ & $\begin{aligned} & 30.9 \\
& \\
& \text { ee p. } 46 \\
& \rightarrow \text { phos } \\
& \text { pyruvat } \\
& \text { ant }(P=\end{aligned}$ & $\begin{array}{l}4 . \\
\text { sphoe } \\
\vec{a} \rightarrow 0 \\
0.05\end{array}$ & $\begin{array}{l}\text { nolpyr } \\
\text { oxaloac } \\
\text { 5). }\end{array}$ & $\begin{array}{l}\text { vate. } \\
\text { tate. }\end{array}$ & NS & $<0.01$ & NS \\
\hline
\end{tabular}

several laboratories (Freedland, Cunnliffe \& Zinkl, 1966; Peret, Chanez, Cota \& Macaire, 1975). Insulin treatment did not significantly affect PK activity in the livers of trout given the $\mathrm{HC}$ diet, this finding also parallels results in the omnivorous rat given diets in which carbohydrate was supplied in the form of glucose (Freedland et al. 1966). PK activity in livers of trout given the HP diet was significantly decreased by insulin treatment; this was surprising as insulin generally acts to enhance glycolytic reactions.

The regulatory role of PEPCK in gluconeogenesis was indicated by the significantly greater activity present in the livers of trout given a HP diet. Preliminary experiments by us on the intracellular distribution of PEPCK in liver of hatchery reared trout have indicated that it is mainly located in the mitochondria (Walton \& Cowey, unpublished results), but it remains to be seen whether the observed changes in activity are due to alterations in the level of cytosolic enzyme or to some more subtle variation in the mitochondrial enzyme. The effect of insulin on PEPCK activity was related to dietary history. The activity of the enzyme was not further reduced by insulin in the HC-fed trout but was significantly reduced in the HP-fed trout. This result was in marked contrast to that obtained by Peret \& Chanez (1976) on rats in which insulin did not alter PEPCK activity at either high $(500 \mathrm{~g} / \mathrm{kg})$ or low $(100 \mathrm{~g} / \mathrm{kg})$ levels of protein intake.

The ratio, 'forward' to 'back' reactions for PEPCK in the crude extracts used in these experiments was low (mean $\pm \mathrm{SE}, 1.38 \pm 0.08$ ) but it was constant irrespective of dietary treatment. A much higher value, 7, was obtained for this ratio for purified PEPCK from pig liver mitochondria (Chang \& Lane, 1966). Our values for trout are similar to those reported for this ratio in crude extracts of rat liver 1.6 (Pogson \& Smith, 1975), but there is no obvious explanation for the disparity between values obtained on the purified enzyme 
Table 3. The effect of treatment with insulin on essential, non-essential and total amino acid concentrations in plasma (mmolll) of rainbow trout (Salmo gairdneri) given diets of different composition*

\begin{tabular}{lrcccc} 
Diet ... & \multicolumn{2}{c}{ High protein } & $\overbrace{\text { None }}^{\text {High carbohydrate }}$ & Insulin \\
Treatment & None & Insulin & 3.05 & 0.94 \\
Total amino acids & 10.20 & 3.09 & 1.35 & 0.42 \\
Essential amino acids & 6.43 & 1.94 & 1.75 & 1.70 & 0.52 \\
Non-essential amino acids & & 3.77 & 1.15 & &
\end{tabular}

and on crude extracts which are usually taken to be physiologically meaningful (Newsholme \& Start, 1973).

GK was not induced in trout by any of the treatments used; as the HK activity was unchanged by the level of carbohydrate intake used there was no apparent increase in the glucose-phosphorylating capacity of the fish in response to diet. Insulin did increase the $\mathrm{HK}$ activity of trout given the HC diet but as this enzyme has a low value for the Michaelis constant for glucose it would be relatively insensitive to large and rapid increases in blood glucose.

FDP activity was increased by gluconeogenic conditions (high-protein intake) but was not affected by insulin.

\section{Amino acids}

All blood samples were taken $18 \mathrm{~h}$ after the trout had last been given food and they are systematic venous samples. The concentrations of amino acids found in the plasma (Tables 3 and 4) should therefore be comparable (or relatively uncomplicated) in terms of possible circadian rhythms and absorptive state. 'Gastric-emptying time' may be very prolonged in salmonids and is markedly affected by temperature; Brett \& Higgs (1970) found that complete gastric digestion for Oncorhynchus nerka decreased from $14 \mathrm{~h}$ at $3^{\circ}$ to $18 \mathrm{~h}$ at $23^{\circ}$. Thus our blood samples were taken while trout were still in the absorptive state. The concentrations of all amino acids, with the exception of the non-protein, aminosulphonic acid, taurine, were much lower in trout given the HP diet; even where differences in amino acid concentration were not significant (tyrosine, phenylalanine, serine) the same trend was evident. The decrease in concentration of essential amino acids in the plasma of $\mathrm{HC}$-fed trout, approximately $80 \%$, was greater than that of non-essential amino acids (approximately $55 \%$ reduction) so that some selective conservation of essential amino acids apparently occurred.

Insulin treatment of both dietary groups led to a reduction in plasma amino acid concentrations. In this instance both essential and non-essential amino acid levels decreased by approximately the same amount, a reduction of approximately $70 \%$ in their concentration. Plasma ammonia concentration was also reduced by insulin in both dietary groups indicating that this hormone reduces amino acid degradation and facilitates protein synthesis and nitrogen balance.

Results obtained for enzyme activities, plasma amino acids and plasma glucose with the streptozotocin-treated fish were the same as those obtained in untreated trout given either the HP diet or the HC diet. Histological examination of the pancreas of these streptozotocin-treated fish showed that the $\beta$-cells were intact and apparently physiologically normal. This is surprising as the same procedure led to diabetes in rats (Bloxam, 1972). Streptozotocin, rather than alloxan, was used in an attempt to deplete the trout of insulin because alloxan is reputed to have side effects including liver damage (Lukens, 1948). 


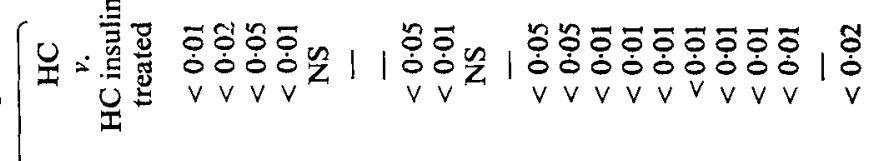

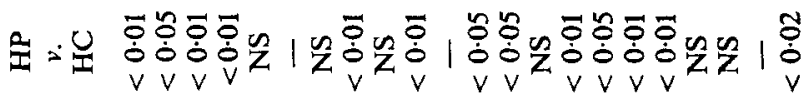




\section{DISCUSSION}

It has previously been shown that trout possess an adaptive capacity to regulate gluconeogenesis in response to changes in diet composition (Cowey et al. 1977). irrespective of the mechanism involved this regulatory control is qualitatively similar to that of omnivorous mammals in that the activities of the key gluconeogenic enzymes PEPCK and FDP are enhanced in response to a HP intake while the activity of the glycolytic PK is decreased. This regulatory control over gluconeogenesis may be particularly important in the trout because the rate and extent of release of glucose from the liver by glycogenolysis is very slow. Thus liver glycogen in a rat is virtually exhausted after a $24-48 \mathrm{~h}$ fast; in carp (Cyprinus carpio), on the other hand, Nagai \& Ikeda (1971) found that in a $22 \mathrm{~d}$ starvation period liver glycogen levels increased from $8.5 \%$ to $10.65 \%$ while blood glucose values fluctuated widely (3.2-6.6 mmol/l). This implies: (1) glycogen is not serving as an immediate source of blood glucose; (2) there is a very low over-all flux between glycogen and glucose, (3) gluconeogenesis is operating to meet glucose demand.

Contrasting with the ability of trout to increase glucose formation in response to dietary change is the fact that blood glucose levels may vary widely, and without apparent detriment to the fish, depending on carbohydrate level in the diet. Factors affecting blood glucose level in mammals have been enumerated by Nordlie (1976); in many animals the liver plays a major homoeostatic role, taking up glucose by virtue of the glucose phosphorylating enzymes (HK, GK) or hydrolysing glucose-6-phosphate (glucose-6-phosphatase) as the situation demands. Uptake of glucose by peripheral tissues is also important; perhaps more so in such animals as ruminants which, although their livers do not contain a specific glucokinase (Ballard, 1965), can control their blood glucose concentration very well during prolonged infusion of glucose (Judson \& Leng, 1973). The inability of trout to control blood glucose concentration closely is, at least in part, related to the lack of any increase in glucose phosphorylating capacity in the liver (no change in HK, no induction of GK) when the glucose intake of the fish is increased. At the same time the peripheral tissues also fail to respond (by enhanced glucose uptake) to an elevation of blood glucose.

Blood glucose levels in mammals are to a great extent controlled by insulin. Immunoreactive insulin levels in the plasma of rainbow trout measured by a radioimmunoassay technique employing cod (Gadus morhua) insulin components varied between 1.60 and $6.80 \mathrm{ng} / \mathrm{ml}$ depending on whether the trout was fasted or fed (Thorpe \& Ince, 1976). The food used by Thorpe \& Ince (1976) (chopped liver and heart) had a high protein content and an apparent correlation between plasma amino acid nitrogen levels and elevated plasma insulin was observed. It may be tentatively inferred from the results of Thorpe \& Ince (1976) that amino acids act as a signal for insulin release in trout; other evidence, the intolerance of trout to a glucose load and the reduction of elevated blood glucose levels by insulin administration (Palmer \& Ryman, 1972), suggests that glucose does not serve as a signal for insulin release in trout. This thesis, should it prove correct, would provide an explanation for results obtained in the present experiment. HC-fed trout having low plasma amino acid levels would also have little insulin released into the circulation, administration of insulin would then be expected to reduce plasma glucose levels which it did. HP-fed trout with high plasma amino acid levels and thus more insulin in the circulatory system would have a low concentration of blood glucose which would be relatively unaffected by administered insulin.

In the absence of information on the amount of other hormones present in the fish and on the inherent sensitivity of responsive tissues to insulin (number of receptor sites) the present explanation is an oversimplification, but there is now substantial evidence that glucose does not serve as a signal for insulin release in rainbow trout. 


\section{C. B. Cowey, D. Knox, M. J. Walton and J. W. Adron}

The main effects of insulin on the enzymes studied were an enhancement of HK in the HC-fed fish and suppression of PEPCK and PK in the HP fish. The suppression of PEPCK by insulin is noteworthy; as Peret \& Chanez (1976) found no effect of insulin on this enzyme in rats, the piscean enzyme may be more sensitive to physiological factors. Whether the enhanced HK activity is great enough to explain the decrease in blood glucose level remains to be seen, other phosphotransferase enzymes have been said to be present in fish (Lueck, Herrman \& Nordlie, 1972) and they may also be accelerated by insulin.

Amino acid levels in the plasma reflect the amounts available to the tissues and the relatively high rate of gluconeogenesis observed previously in trout given $\mathrm{HP}$ diets must be partly due to the greater availability of substrates. The hypoaminoacidaemic action of insulin demonstrated in trout has long been known to occur in mammals (Luck, Morrison \& Wilbur, 1928). The mechanism involved in fish remains to be elucidated, but it is known that insulin greatly stimulates incorporation of radioactive glycine into muscle protein in toadfish (Tashima \& Cahill, 1968) and it seems likely that an acceleration of amino acid uptake by muscle is a major factor in the hypoaminoacidaemic action of insulin in fish.

The authors thank Dr P. T. Grant for his continued interest in this work and for his critical comments during its course.

\section{REFERENCES}

Ballard, F. J. (1965). Comp. Biochem. Physiol. 14, 43.

Ballard, F. J. \& Hanson, R. W. (1967). Biochem. J. 104, 866.

Bloxam, D. L. (1972). Br. J. Nutr. 27, 249.

Brett, J. R. \& Higgs, D. A. (1970). J. Fish Res. Bd. Can. 27, 1767.

Burleigh, I. G. \& Schimke, R. T. (1968), Biochem. Biophys. Res. Commun. 31, 831.

Chang, H-C \& Lane, M. D. (1966). J. biol. Chem. 241, 2413.

Cowey, C. B., Higuera, M. \& Adron, J. W. (1977). Br. J. Nutr. 38, 385.

Freedland, R. A, Cunnliffe, T. L. \& Zinkl, J. G. (1966). J. biol. Chem 241, 5448.

Johnson, J. A. \& Fusaro, R. M. (1966). Analyt. Biochem. 15, 140.

Judson, G. J. \& Leng, R. A. (1973). Br. J. Nutr. 29, 159.

Krebs, H. A., Dierks, C. \& Gascoyne, T. (1964). Biochem. J. 93, 112.

Luck, J. M., Morrison, G. \& Wilbur, L. F. (1928). J. biol. Chem. 77, 151.

Lueck, J. D., Herrman, J. L. \& Nordlie, R. C. (1972). Biochemistry, 11, 2792.

Lukens, F. D. W. (1948). Physiol. Rev. 28, 304.

Nagai, M. \& Ikeda, S. (1971). Bull. Jap. Soc. Sci. Fish. 37, 404.

Newsholme, E. A. \& Crabtree, B. (1973). FEBS Lett. 7, 195.

Newsholme, E. A. \& Start, C. (1970). Regulation in Metubolism, London: John Wiley \& Sons.

Nordlie, R. C. (1976). Trends Biochem. Sci. 1, 199.

Opie, L. H. \& Newsholme, E. A. (1967). Biochem. J. 103, 391.

Palmer, T. N. \& Ryman, B. E. (1972). J. Fish. Biol. 4, 311.

Peret, J. \& Chanez, M. (1976). J. Nutr. 106, 103.

Peret, J., Chanez, J., Cota, J. \& Macaire, I. (1975). J. Nutr. 105, 1525.

Pogson, C. I. (1968). Biochem. Biophys. Res. Commun. 30, 297.

Pogson, C. I. \& Smith, S. A. (1975). Biochem. J. 152, 401.

Seubert, W. \& Huth, W. (1965). Biochem. Z. 343, 176.

Tashima, L. \& Cahill, G. F. (1968). Gen. Comp. Endocrinol. 11, 262.

Thorpe, A. \& Ince, B. W. (1976). Gen. Comp. Endocrinol. 30, 332. 